\title{
A Nurturing HQ Is Good for the MNC
}

\author{
Yezdi H. Godiwalla ${ }^{1}$ \\ ${ }^{1}$ Formerly of: Management Dept., College of Business and Economics, University of Wisconsin-Whitewater, USA \\ Correspondence: Yezdi H. Godiwalla. E-mail godiwaly@uww.edu
}

Received: August 8, 2018

Accepted: August 29, 2018

Available online: August 30, 2018

doi:10.11114/ijsss.v6i9.3581

URL: https://doi.org/10.11114/ijsss.v6i9.3581

\begin{abstract}
Good parenting, nurturing, training and close networking within the organization by the headquarters are very vital for the overall MNC. An MNC's HQ must pursue better nurturing and fostering developmental and networking approaches in its relationships with its foreign subsidiary units. A well supported and nurtured constellation of foreign subsidiaries will perform more cooperatively and harmoniously within the framework of the overall MNC organization. In turn, these approaches will generate more effective strategies for competitive performance because of the improved cross-fertilization of ideas. This is for younger and mature organizations because of the inherent hierarchical difference between the HQ and the foreign subsidiaries. The HQ must pursue a spirit of collaboration and partnership that would generate a feeling of near equality among the partners. HQ may give the final assent even so, only after good deliberations and factual and rational analyses. Good nurturing and close communications would likely align the values and views of the many disparate foreign units, given the diverse environments of operations. Learning in an MNC organization, which has these collaborative, closer internal and stakeholder networking, communicative attributes, is multi-directional: HQ learns as much from the foreign subsidiary units as the units learns from the HQ. Closer internal and external stakeholder networking in an MNC and good parenting and nurturing involve good, continuous expatriate training. These activities result in better organizational effectiveness and competitiveness.
\end{abstract}

Keywords: collaborative MNC, nurturing MNC executives, MNC HQ-foreign subsidiary unit relationships

\section{Introduction}

There was a study of the behavior of mice which was reported by Begley (2000) on the experimental works of Michael Meaney of McGill University, Montreal. It was contrasting: (a) the calm, problem-solving behavior of mice that were pampered and loved (nurtured), from those (b) who were not pampered and not loved (not nurtured) by their mother mice. The mice that were pampered and loved (nurtured) by their mothers "had their brains turned on high", compared to the non-loved mice. Begley (2000) said about Meaney's findings which indicated that the well-loved mice (whose mothers kept sucking their heads like lollipops) "did not startle easily and were less fearful of novel situations". They were much braver and dared to take greater risks. They were calmer too. However, Meaney's findings indicated that the un-loved mice were nervous and unsure of coping with novel situations; they did not show any problem-solving capabilities. "Their brain genes were not turned up as high, although such (or same) genes were present." These mice were nervous, flustered and easily gave up. Similar studies by Tsien (2000) reveal that mice can be re-molded to display different attributes. Nurturing, on a sustained basis, is good for problem solving and in coping with strange, unfamiliar situations.

Speaking broadly, beings (humans or rats) have inherent genes which could be turned on "high" through careful, patient and affectionate nurturing. One's life experiences work on one's genes (yes, the same genes) and one takes shape, either to be confident and successful, or otherwise. It is possible to work on the genes and turn a person around to be different. It is possible, with patience, persistent and affection, to take the same genes of a being and re-shape the being. For example, in spite of the natural propensities of an introvert child to be reticent and withdrawn, his guardians (parents, teachers, relatives, friends) can re-shape the child to become more extrovert and gregarious.

The father of President Theodore Roosevelt had encouraged him to become more outdoorsy despite his physical withdrawal and his tendency to be a withdrawn reader. It is said, "Roosevelt was born a sickly child with debilitating asthma, but he overcame his physical health problems by embracing a strenuous lifestyle". His father worked on his son against the grain. With the help and encouragement of his father's re-shaping of him, he did become much more robust and gregarious in all his later adult life (Hart and Ferleger, 1989). His father's values and his invisible moving hand had help to re-shape him. He continued to be a scholar and also became very physically active. Roosevelt said of his father, 
"My father, Theodore Roosevelt, was the best man I ever knew. He combined strength and courage with gentleness, tenderness, and great unselfishness. He would not tolerate in us children selfishness or cruelty, idleness, cowardice, or untruthfulness." Innately, he had followed his father's advice as if his father had most actively shaped him. His father had augmented his personality beyond his original self. Thus, guardians (parents, teachers, relatives) "nurturing against the type" of a child can work to re-shape the child from his in-born to the new-born person. In re-shaping the child, parents too can become re-shaped. Re-shaping is a two way process, an important observation to remember as we apply this idea to HQ people nurturing and re-shaping the foreign subsidiary executives.

The idea that we should work on human beings when they are much younger has often greater currency. One may ask: But what about adults as they go about their challenging lives, balancing work and family expectations? And how would nursing home geriatric persons respond to such approaches? It seems viable to apply the tenet to older generations of people as well. The notion of caring and re-shaping has been successfully applied to grownups. Schellenbarger (2000) cites that in Massachusetts, day care centers have been caring for stressed young parents as they cope with the dual challenges and stresses of work life and family life. In a "paradigm shift," Bright Horizons Family Solutions, which operates 300 centers in Massachusetts, has renamed its child care centers "family centers." It promotes overall family well-being and help to nurture balance in parental lives too. Again as in the previous analogy, applying this issue to MNC situation, HQ executives are also themselves going to be re-shaped as they nurture the foreign subsidiaries' executives.

For an MNC, closer partnering, expatriate training, nurturing are important on-going managerial efforts. They would make the overall MNC executives to be collectively responsible and responsive to their respective task environments. Like the well-loved and well-adjusted mice, they will confidently respond to novel situations. Applying this issue to the MNC situation, the more well-loved and well-adjusted the foreign subsidiary unit executives, the better will be the performance of the foreign subsidiary units.

For an MNC, closer partnering, expatriate training, nurturing are important on-going managerial efforts. They would make the overall MNC executives to be collectively responsible and responsive to their respective task environments. Like the well-loved and well-adjusted mice, they will confidently respond to novel situations. Applying this issue to the MNC situation, the more well-loved and well-adjusted the foreign subsidiary unit executives, the better will be the performance of the foreign subsidiary units.

\section{Review of Literature}

Expatriate training, mentoring and training of current foreign subsidiary executives, nurturing and closer networking and collaboration (among HQ and foreign subsidiary units' executives) are vital for an MNCs because of the very many complex and diverse and difficult sub-environments with which the different peoples in the MNC work and not all of them are familiar with the situations across the world, and, for which they would need periodic training (Aguzzoli and Geary, 2016; Godiwalla, 2017; Ioannou, 1994, Rosenzweig and Singh, 1991; Sundaraman \& Black, 1992). The diverse international environments pose real challenges for the international managers, and, they perform better if they were better and continuously trained and nurtured (Ebrahimi and Grieu, 1999; Finkelstein and Hambrick, 1996; Kamonche, 1996; Otterback, 1981; Sundaraman and Black, 1992).

The complex and dynamic nature of the different environments of an MNC's foreign subsidiaries make the preparedness and training efforts more challenging for the MNC headquarters (Godiwalla, 2014). There are several reasons for these diversities, including: (a) the ever-shifting organizational cultures and processes of the foreign subsidiary units (Brief, Guzzo and Schnieder, 1996; Galphin, 1996; Want, 1993); (b) the greater want for more effective control and influence by the MNC HQ over its foreign subsidiary units (Chang and Taylor, 1999); (c) the improving of the R\&D of its foreign subsidiary units so that they would out-perform the competitors in the local and regional markets (Murlidharan and Phatak, 1999); (d) the more effective adapting and formulating strategies by the foreign subsidiary units and improve the conduct of expatriate behavior in the local cultural setting (Newsweek, 2000; Robertson and Fadil, 1999); (e) the more effective negotiations with host country players (Vachani, 1995); (f) the improving of the competitive advantage of foreign subsidiary units (Collis, 1998; Duncan, Ginter \& Swayne, 1998; McLaughlin, 1999; Porter, 1997); (g) the better innovation in foreign units (Hamel, 1998); and (h) the focus on ethical conduct for the overall MNC. Nurturing is vital in the process of improving the long term betterment. The focus should be of the interests of the re-shaping of the future directions and future destiny.

The better and frequent nurturing and training strategies may emphasize several of these issues as a foreign subsidiary unit executive would address his activities. The better is the nurturing; the better will be the performance of the foreign subsidiary units. Therefore, positive reinforcement and encouragement are the hallmarks of sustained growth and also creative and innovative performance. Any negative or discouraging overtures by the HQ upon foreign subsidiaries are detrimental to any long term performance.

The scope, nature and content of the interactions between the HQ and the foreign subsidiary units must be laid clear for all. 
For example, the scope, nature and content could specify to be: (a) the top-down and bottom-up, dual directional, real-time data and information exchange, discussions and analyses, and, the proposing of essential rationales for strategic decision making for all levels, HQ to foreign subsidiary units (Godiwalla, 2017); Gupta and Govindarajan, 1991); and (b) the quality of agreement on current issues and future directions as they are vital for increased competitiveness (Nohria and Ghosal, 1994). These issues and content of the various essential rationales for strategic decision making are most important for the various level of the MNC to discuss and agree so they will act in some synchronized manner and , through greater delegation and guidance, the foreign subsidiary executives will take increasing role of active decision making such that the foreign subsidiary units will be prompt and complete in their strategic and operational responses to their task environments (Godiwalla, 2004; Gupta and Govindarajan, 1991; Williams, 2009).

The effectiveness of the courses of an $\mathrm{MNC}$, as it forges into the future of different global arenas, is determined by the quality of coherence and clarity of its underlying central core strategic rationale. The clearer the central core strategic rationale and the more coherent then central core strategic rationale, the better will be the comprehensive network of overall MNC strategies. Frequent and concurrent counselling and discussions at both locations, the HQ and the foreign subsidiary units, by the HQ executives and continuous feedback by the foreign subsidiary units' executives, particularly given that the MNC situation is characterized by the very diverse and complex nature of operating environments in the context of a MNC operating in diverse cultural and operating environments (Fish and Wood, 1996; Godiwalla, 2004; Haddock and South, 1996; Laabs, 1996). It is important that the organizational culture of mutual respect between the HQ and the foreign subsidiary units and a higher to improve the quality of sensitivity and appreciation of the decision making and operating situation by both sides as the overall organization strives to seek coordinated approach of mutual respect and collaborative approach to improving the combined performance of the MNC. It may be mentioned that the more rounded manager and the versatile executive with many skills and interests are the correct attributes to emphasize. It is also worthwhile to encourage more rotation-type of approaches to human resources management practices for placing different executives for short overseas stints of assignments. That approach will engender greater empathy and understanding.

Many issues of pre-departure managerial expatriate training followed by intense post-arrival mentoring and upgrading of skills and perspectives, are most worthwhile (Fish and Wood, 1996; Godiwalla, 2004; Harris, 1997; Ioannou, 1994). The important issue here is that that competitive performance and organizational growth of an MNC on all its fronts requires sustained nurturing and mentoring on an MNC organization-wide basis (Chawonec and Newstrom, 1981; Harris, 1997).

\section{The Purpose the Paper}

The paper provides arguments that emphasize the importance of continuous nurturing, mentoring, training, partnering and frequent and closer discussion by HQ and the foreign subsidiary units. It also reviews the assumptions of essential rationales for strategic and operational decision making among the HQ and foreign subsidiary units. Competition, external environmental changes and the pressure for sustained organizational growth and organizational scope enlargement as in the spheres of global operations make this focus on closer and collegial HQ-foreign subsidiary units' relationships even more important. It is vital for long term survival and growth for the MNC as a whole.

High levels of unconditional empathy and real involvement among HQ executives in the foreign subsidiary units' activities from a not-too-frequent, fully collaborative and helpful, supportive manner would be truly beneficial. Well-coordinated and well-organized discussions will bring to surface more issues upon which the HQ and foreign subsidiary units' executives can jointly analyze, deliberate, decide and act.

\section{Closer Collaboration, Nurturing, Training and Progress towards "Internationalism"}

An MNC should improve the "internationalism" (a wider and greater appreciation of situations and peoples of the other parts of the world) among all its executives and supervisors throughout the MNC. This is a long term endeavor and it would involve many people in the MNC. Such an endeavor should involve people such as: executives, managers, supervisors and specialists. This would include people in the MNC home country and foreign subsidiary units' host countries as well.

Many leading international organizations have planned focus on international human resource development, and, these are perceived to pay off over a period of time. The focus upon international human resource development is pursued by major international organizations, as is evidenced in annual reports of some corporations, e.g. GE Annual Report, 2017.

Development of human resource has a significant impact upon an organization's performance. In Fortune's “America's Most Admired Companies" (Fortune, 2018), the companies' performance on employee talent and quality of management significantly correlates with the companies' performance as judged by their ranking in the top and bottom list of 500 firms were analyzed in the survey. The top firms in the list which had very high ratings for employee talent and quality of management were significant in their human talent development. Examples of the top companies are: Apple, Amazon, 
Alphabet, Berkshire Hathaway, Starbucks, Walt Disney, Microsoft, Southwest, FedEx, JP Morgan, Netflix, Facebook, Costco Wholesale, American Express, salesforce, Nike, and Johnson and Johnson. They also performed well on rate on total return, a measure for shareholders interest.

Conversely, the bottom companies in the list have very low ratings on employee talent and quality of management. They were also the least admired and they also least served their stakeholders, including the shareholders. Thus, international human resource development is a long term pay off and firms have to take a longer term perspective. Developing and nurturing high quality top executives and specialists and other levels of human resource must be considered a top priority in organizations.

\section{MNC's Nurturing and Training for Foreign Units' Executives}

Nurturing should be a sustained and long term in orientation, and, it should be an organization-wide effort. It should be characterized by unconditional understanding, trust, support and collaboration among the executives of the HQ and the foreign subsidiary units. Important issues should be openly and freely raised and discussed. HQ's executives must embrace "full immersion" in the foreign subsidiary units' local and regional values, cultures, conditions and environments. They should understand the local and regional values in the greater spirit of internationalism. This deliberate HRM process of nurturing such local values world-wide would enable HQ executives to honor foreign subsidiary executives' challenges and accomplishments. This spirit will foster greater partnership culture. In turn, it would increase the world-wide and international values and it would attract better future international executive recruits. Additionally, better HQ executives will venture to take foreign assignments.

Greater HQ domination in developing and pursuing HRM and training policies would lead to a greater standardization of world-wide practices. However, it would overlook local initiatives that would optimize the cultural antecedents. Management is culture bound. The inviting of a broader participation that allows for inputs from foreign subsidiary units would lead to a richer global HRM practices. Thus, there would be a much mature approach by foreign units on issues of HQ's and foreign subsidiary units' strategic and operational control. Though there are trade-offs of each approach (HQ-domination, versus, greater foreign subsidiary unit involvement), greater headquarters driven approach would cause a drive towards uniform globalization of management development. There are no clear cut arguments that can be applied universally across the board. It must be on a case-by-case basis. It would depend on the organization at a given point in time. Thus, greater foreign subsidiary units' propulsion in the HRM policies development could result in focus on local issues and, consequently, on increasing autonomy of the foreign subsidiary units, the local circumstances would drive future strategic and operational scope and their respective decision outcomes. In this context, HRM policies (particularly those of mentoring, nurturing and training) would influence the strategic and operational decision making process in the MNC organization.

\section{MNC HQ's Interventional and Nurturing Strategies}

A question may come up: How should an MNC's HQ intervene as it seeks to improve the foreign subsidiary units' performance through improved nurturing? This involves injecting (intervening) HQ action in the foreign subsidiary units. Most MNC HQ offices have some degree (little, moderate, high, very high) of internationalization. How much it is throughout the MNC organization is a good and relevant question. The greater the degree, the more receptive would be the nurturing and collaborative process. Understandably, not all MNC HQs display equally very high degree internationalism and many MNC HQ's product and business divisional executives are results-oriented (about their own respective task environments), and, they are often far removed from international business activities or the activities of the foreign subsidiary units. There is also less empathy with them. An MNC HQ must choose particular effective interventional strategies in dealing with issues within foreign subsidiary units, such as rapid, closer and detailed involvement and engagement, or, gradual and broader engagement, as it seeks to nurture and collaborate with the foreign subsidiary units.

Top management of the MNC should encourage its HQ executives and specialists to becoming more supportive, empathetic and sensitive to foreign subsidiary units' executives (Fish, 1996; Laabs, 1996; Barnum, 1994). There should be greater rapport. The HQ executives should foster in themselves more internationalism such that they would pursue their full collaborative approaches as they interact with foreign subsidiary units' executives. In turn, they themselves may in time become ripe candidates for foreign postings and assignments. Over time, they will show a greater propensity for internationalism in their thinking so that it would improve the MNC's performance in its international activities because of a truly collaborative style. This growth process can be induced by positive interventions by the MNC's top management, rather like the nurturing of the rats. The top management should work on the HQ executives and foreign subsidiary units' executives.

Among the home country executives and technical specialists there may be a tendency to focus upon the particular methods of the MNC's units within the home country as being the "one best" way of doing it. There can be a tendency to regard other approaches of other countries' economies and cultures of the MNC's foreign units to be less optimal or inferior. It is suggested in the table that MNCs must encourage a more open, receptive and interactive-oriented culture 
among its executives and technical specialists, both in the home country as well as in its foreign units, so that the MNC becomes more effective in its international business activities in all its foreign units and in its headquarters.

\subsection{The Joseph Salmons Model (2015) of "Vertical" and the "Horizontal" of Interventional Migrations}

Joseph Salmons (2015) has introduced the models of "vertical" and "horizontal" migrations and language transfers. He studied the patterns of language transfers from an (invading) migration of superior skilled and resourced peoples of one region to another region which have lesser skilled and resourced peoples. Such migrations can be either peaceful or in the form of an aggression. "Aridization" of lands and consequent fears of starvation can lead to mass or stage-by-stage migrations of the affected peoples to transfer to other more favorable areas. Language and culture transfers mostly also follow. The process of assimilation between the two sets of peoples can be "vertical" or "horizontal".

Salmons (2015) states:

“... systematic changes in community structure are what drive language shift, incorporating Milroy's network structures as well. The heart of the view is the quintessential element of modernization, namely a shift from local community-internal organization to regional (state or national or international, in modern settings), extra-community organizations. Shift correlates with this move from pre-dominantly "horizontal" community structures to more "vertical" ones."

It is "vertical" when the some of the host populations want to adopt the languages and practices of the inward migrations. This was the case of the British colonial invasions when many of the host peoples wanted to learn and ostensibly adopt the English language, the British education, customs, methods, knowledge and ways of life because they perceived them to be elite or prestigious. In many cases, the host peoples retained their cultures and customs in personal and family lives, but adopted the professional knowledge and technical practices from the British. It is called "vertical" because the in-migrating people bring into the host country newer languages and the host people want to "climb upwards' to adopt the incoming language and other practices. As a consequence, the transfer of the perceived more desirable professional, administrative and educational systems, knowledge-based activities of the British also helped the host countries' peoples to come closer with the rest of the advanced Western world and brought them closer to the current times. Applying this idea to MNC HQ's executives who, as expatriate managers in the regional HQs and foreign subsidiary units are able to significantly change (for the better) the local practices of the foreign units executives. When the MNC HQ's practices are perceived to be better or more effective, then the foreign subsidiary units will want to "climb upwards" and adopt the HQ prescribed methods. The Japanese MNCs are stronger in their HQ methods and values as they manage their foreign subsidiary units, as in case of Matsushita (of Japan). These are essentially top-down flows, that is, from the emanating regions (or, the MNC HQ) to the receiving regions or host countries (or, the foreign subsidiary units).

Further, one can also project a "reverse" variation of the "vertical' model. That would take place when the foreign subsidiary units are providing significant upward flowing inputs to the MNC HQ, as in the case of the autonomous Philips (of The Netherlands) foreign subsidiary units creating newer products and providing other "upward" flow.

It is "horizontal" (in the case of the Joseph Salmon model) when the migrating languages do not change the linguistic patterns of the host country peoples. The host country peoples continue with their own languages and do not allow for osmosis or assimilation to take place. In the case of the MNC, if the MNC HQ's practice transfers are not in abundance or forceful enough, then there is little or no "vertical" transfer, but the "horizontal" (or within the host country) process continues.

\subsection{Indifference for or Aloofness to Anything Different and Difficult to Understand}

A persistence of ignorance and even dislike of anything that is foreign to one's way of thinking or doing, as in the case of a driver of a broken down semi-truck from New York getting no cooperation in getting repairs for his truck in the southeast US simply because he is different. This tendency is natural, although not conducive for better international understanding, for many people who are not exposed to other country cultures and who might even feel offended because they are so used to their own cozy culture. The MNC HQ's top management must provide means and rewards to interact with and understand peoples of very different cultures. This will have a desirable effect on the HQ staff for understanding their global markets and operating conditions, from one global quarter to another.

\subsection{Close Knit Groups}

Many primary task employees of an organization tend to have relatively stable work groups (e.g. a group of five people working together for fifteen years become closely coordinated in their working). This approach tends to make its core members inward looking and therefore quite "closed" in their outlook. Such groups, with their membership quite solidified, tend not to open up to other groups. This hardening of one-group, core mind-set approach is not conducive to internationalism. MNCs must encourage opening up work group composition to include other groups' views in close working relationships. To start with, other groups could include groups from different parts of one country, or, of nearby countries. Such approaches generate openness and extrovert-ness 


\subsection{Culturally Restrictive and Reticent Executives and Specialists}

It is understandable to feel more comfortable to flock together with others of the same culture (e.g. Thai students in the US would spend much of their time together). However, this leads to ineffectiveness in leading and motivating people of other cultures. Leadership in diverse cultural settings leads to improved skills for international organizational performance.

This is a common malady among many operations focused firms. Once they achieve a degree of near optimization among its operational variables, then they want to buffer it from the vagaries of external dynamics. They also do not want to disturb its internal arrangements of organizational factors of production (or operation). That would include: little or minimal changes in the deployment of executives and specialists except those necessitated by vacancies arising from promotion, illness or retirements. But to progress and be better prepared an organization must be ready to undergo changes even though these changes in themselves may be disruptive. The tradeoff is better long term organizational preparedness for international business.

\section{MNC HQ's and Foreign Units' Efforts Toward Strategic and Operational Control and Coordination Processes}

Strategic control and coordination issues at the foreign unit level are the heart of MNC headquarters-foreign unit relationships. These issues take different form in various discussions.

In the evolution of their growing internationalization, firms grapple at these two opposing forces of integration and differentiation as they seek their preferred "balance" between: (a) headquarters needs for synthesis, close coordination and integration at the strategic and operational levels, and, (b) foreign units' need for autonomy and responsiveness to host country and regional environmental dynamics. These issues have been discussed in various places in literature, a sample of which are captured in the anthology by Otterbeck (1981) and the specific firm examples and approaches in articles such as those by Haddock and South (1994), Gupta and Govindarajan (1991), and Evans and Lorange (1989). Implicit in these discussions is the issue of whether locus of control, influence and direction of (a) strategy, (b) coordination, and (c) operations are going to be: (a) predominantly at headquarters; (b) predominantly at the units; or (c) jointly shared by the headquarters and the units.

Kamoche (1996) presents the issue in the form of integration (or, headquarters focused approach), and differentiation (or foreign unit focused approach). His conclusion is that an optimal approach would include: (a) resource heterogeneity, i.e. diversity in international human resource education, skills, cultural backgrounds, and stakeholder contacts at unit level; and, (b) organizational learning, i.e. the MNC's ability "to build on competencies that have been generated in one business activity or one region and to utilize these in other business activities or regions" (Kamoche, 1996).

Examples of MNCs that pursue global integration are IBM, Unilever, Hewlett-Packard, Procter and Gamble, General Electric and the very centralized Matsushita. Most of these firms stress a broad, central coordination of all major strategies and policies. On the other hand, those other firms which stress local responsiveness are Philips, General Electric Company (of UK), Nestle, American Express and ITT. These firms believe to a greater extent in allowing their foreign units to develop their own strategies and policies. The organizational rationale for centralized coordination is to coordinate more efficiently and economically, thus achieving economic improvement of the use of its global resources. The organizational rationale for the decentralized approach is to focus on local adaptation needs, implying the local responsiveness will indirectly lead to global optimization in the long run.

While the globalization approach makes a case for integration and a uniform management development (as pursued by Unilever). However, cultural differences among countries make a MNC focus on local responsiveness, adaptation and differentiation. Such models of structure and culture provide some flexibility of adjusting to the unique circumstances of the global organizational setting for generating growth and competitiveness.

To achieve better "balance" between the two opposing approaches, a MNC should follow a common (jointly developed by MNC headquarters and all foreign units through effective partnership between them), overall strategic vision and management development philosophy for the enterprise, then adapt that general vision to the local conditions for different regions and countries on such details as: selection, training, performance appraisal, assessment, compensation rewards, socialization, and detailed management development and succession phans. 


\section{The Strategic and Operational Decision Making Process in an MNC, using Good Nurturing (Table 1)}

Table 1. Strategic and Operational Decision Making Process in an MNC: A Nurturing, Cooperative and Collaborative Model

Phase 1

\begin{tabular}{|c|c|}
\hline $\begin{array}{l}\text { MNC's } \\
\text { Corporate } \\
\mathrm{HQ}\end{array}$ & $\begin{array}{l}\text { Overall MNC broad, } \\
\text { long term goals } \\
\text { comprehensive, } \\
\text { integrated organ'l } \\
\text { strategy. } \\
\text { HQ seeks (near) } \\
\text { consensus on } \\
\text { broader issues } \\
\text { among all business } \\
\text { divisions and foreign } \\
\text { units }\end{array}$ \\
\hline $\begin{array}{l}\text { Regional, } \\
\text { And } \\
\text { Divisional } \\
\text { HQs }\end{array}$ & $\begin{array}{l}\text { Regional units } \\
\text { suggest their goals } \\
\text { and strategies. } \\
\text { Provide regional } \\
\text { units, in conjunction } \\
\text { with business and } \\
\text { foreign units, provide } \\
\text { ideas inputs, new } \\
\text { mkt opportunities, } \\
\text { ideas, strategies }\end{array}$ \\
\hline $\begin{array}{l}\text { Business } \\
\text { Units, } \\
\text { Foreign } \\
\text { Units }\end{array}$ & $\begin{array}{l}\text { Business units' and } \\
\text { foreign units' goals, } \\
\text { strategies. } \\
\text { Provide inputs }\end{array}$ \\
\hline $\begin{array}{l}\text { Depart- } \\
\text { ments }\end{array}$ & $\begin{array}{l}\text { Depts' goals and } \\
\text { strategies. } \\
\text { Provide inputs } \\
\text { having practical } \\
\text { usefulness for them }\end{array}$ \\
\hline
\end{tabular}

Phase 2

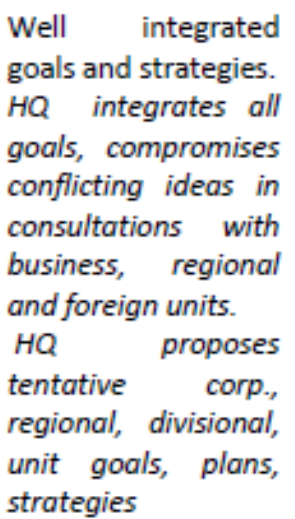

Departments make dry runs of the proposed ideas, suggest refinements

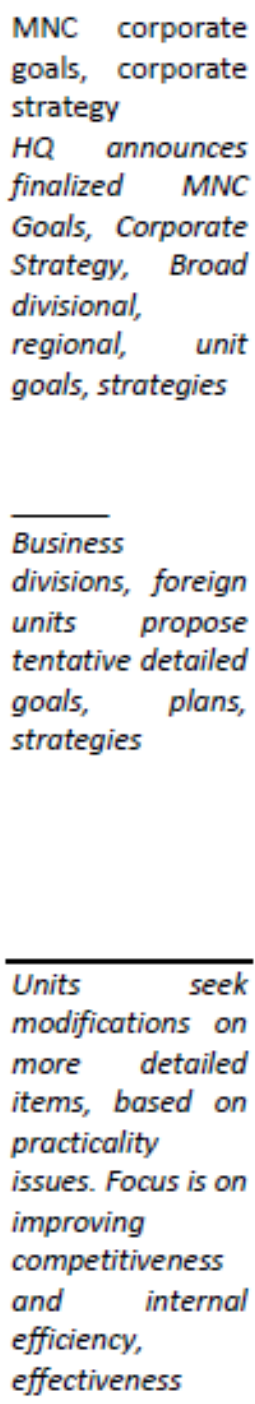

Units seek modifications on more detailed items, based on practicality issues. Focus is on improving competitiveness and internal efficiency, effectiveness

Depts formulate

detailed

procedures, systems, set detailed targets, strategies, operating policies, budget for each quarter

Table 1 provides a four phase approach to effective strategic and operational decision making process such that good communication at all stages of the process is maintained. The good nurturing would engender good inter-personal confidence and trust among the executives at all levels of the MNC organization. Good flow of information and good sharing of real time data and developments (e.g. technological and competitive) would enable the discussions to produce more viable and realistic decision outcomes. Greater mutual understanding and better training at all levels would enhance the quality of decisions and the implementation would also be beneficial.

The approach of the Table is to start with the broadest proposed objectives and goals and, most importantly, allow for all the lower levels to provide ideas and inputs in the formulation and finalization of the objectives and goals and strategy for the MNC as a whole. Then it proceeds to the next level, namely those of business division and regional offices and the foreign subsidiary units with regards to the formulation of their respective objectives and goals and strategies.

\section{Conclusions and Recommendations for Actions}

It is important to recognize the conclusions and recommendations are inter-related in this section. Some of the issues of 
good leadership and good supervisor management styles which we associate with organizational behavior in a general or domestic context would also apply in the international setting. Good management styles, in the broadest terms, would be worthwhile to review as we apply them to the MNC HQ-foreign subsidiary unit context.

MNCs have to find effective ways to make their HQ executives, supervisors and specialists become more international in their outlook and more empathetic with the regional units' and foreign subsidiary units' peoples.. These approaches would help in improving the performance of the MNC. It would benefit from the following approaches: (a) creating a "linking pink" organization (Likert, 1961, p. 113) for better communication across the width and height of the entire MNC organization; (b) a systematic, well-orchestrated agreement between the headquarters and the foreign units regarding long term, overall objectives of the MNC as a whole; (c) provide some strategic autonomy for foreign units to seek local entrepreneurial opportunities; (d) provide significant operational autonomy to the foreign units to manage their local operating situations; (e) improved nurturing of all its people at the headquarters and all the foreign units to become more international; (f) better use of management development approaches (including an extensive use of "intranets" for training) and appropriate use of expatriates from headquarters country, unit's local nationals, and third country nationals; and (g) to train their executives at all levels to “always adapt his (leader's) behavior to take into account the expectations, values, and interpersonal skills of those with whom he is interacting" (Likert, 1961, p. 95), implying that an HQ executive must first understand the foreign subsidiary unit executive's construct and perspectives before he interacts with him. MNC's nurturing of its present and potential international and domestic executives can make a long term difference in the spirit of "internationalism" inside the MNC. MNCs must pursue an aggressive interventional nurturing approach to develop better MNC capability in order to manage globally and locally. Short duration job rotations of HQ and foreign subsidiary units' executives would be helpful.

The relative approaches of headquarters domination or foreign unit domination in the strategic and/or operational control of the foreign units should be correctly analyzed and periodically re-assessed. Fast growing MNCs with dramatically competitive forces should seek greater influences of both headquarters and foreign units in an intense interactive partnership mode. Further, good supervisory styles in the inter-face between HQ and foreign subsidiary units are vital for good organizational performance (Likert, 1961, p. 15). Good leadership by HQ's top executives is vital. It sets the tone of the inter-relationships between other HQ's executives and foreign subsidiary units' executives. Leadership which is characterized by greater mutual respect, autonomy, cooperativeness and problem-solving would result in improved and favorable organizational performance (Likert, 1961, p. 25).

Combined meetings and joint and well-coordinated activities of HQ executives and foreign subsidiary units' executives should lead to a more unified and systematic strategic and operational growth approach at the HQ and foreign subsidiary units levels (Godiwalla, 2004; Williams, 2009). When there are conflicts between the MNC's global interests and local interests, then there is even greater need for the HQ and foreign subsidiary units to more closely discuss for understanding the causes of the situation so as to separate: (a) the different issues on which it may be more beneficial for the MNC to adopt a global approach, (b) the other issues on which it may be more beneficial to adopt a more foreign subsidiary units' orientation, and (c) the remaining issues on which it may be more beneficial to adopt a more combined approach of HQ and foreign subsidiary units.

MNCs should pursue greater global, strategic focus and allow for wider latitude of operational flexibility for the foreign subsidiary units so that the MNC is more focused on contemporary events and on changing realities on real time basis on issues and events of: competition, market trends, technological changes, supplier dynamics and local and political economic trends. This operational flexibility is achieved through an organized network of communication and well forged partnership between the executives in the headquarters and the foreign subsidiary units.

Internal control process inside the MNC is an important consideration because it directly affects the nurturing process. Excessive, depreciative and coercive control process will almost certainly go counter to nurturing outcomes. Thus, control emanating from the HQ is an important factor. It is argued that the national culture of a country affects the internal control process of an organization (Pauly and Reich, 1997). If the national culture of the HQ is hierarchical and rigid, the likelihood is that the organization will have a similar pattern of control process. National cultures therefore are the primary issues to study as we study the internal control process. They cite US has liberal democracy, German has social democracy, has developmental democracy. These national political institutions are the founding sources of an HQ's control process. They generate a pre-emptive influence upon the overall organizational control process. For example, Pauly and Reich cite that such influences generate the dominant economic ideologies of free enterprise liberalism for US, social partnership for Germany, and techno-nationalism for Japan. To argue further, the evaluation process and, therefore, the control process, of foreign subsidiary units for US MNCs tend to be more result-oriented, that is they use finite, quantitative and objective measures. However, the Japanese MNCs' HQs use more insightful, understanding and qualitative approaches in the evaluations of the foreign subsidiary units. For internal growth and providing resources and financing, US MNCs are more detached and less intimate. They are more decentralized and push the decision-making 
down to the foreign subsidiary units, placing the responsibility of results squarely on the shoulders of the foreign subsidiary units. This is sort of approach of "you decide and we will hold you fully responsible for the total results". On the other hand, the German and Japanese MNCs are more centralized. Financial decisions as they relate to long term capital expenditures and other projects are more centralized. There is greater collaboration and participation between the HQ and foreign subsidiary units. These approaches do reflect the character and values of then national cultures (Birkenshaw, 2001; Pauly \& Reich, 1997).

Innovation simply cannot be dictated or mandated. It cannot be top-down. Creativity can take place in unexpected locations and at unexpected times. Spontaneity and freshness of atmosphere can stimulate and foster the creative spirit. Innovation is often not planned and it can take place anywhere, either at an MNC HQ's R\&D centers or in foreign subsidiary units. It is fair to conjecture that it is more likely to take place where there is more nurturing and free fostering atmosphere. Bureaucratic and rigid controls and approaches are less likely to spur true innovativeness.

Examples of significantly decentralized innovation in MNCs are useful to consider. Philips of The Netherlands is strong on decentralized $R \& D$ process because of the very long tradition of innovation-active foreign subsidiary units when it comes to product and process innovations. (By contrast, Matsushita, Philips' Japanese archrival, is very centralized.) Similarly, in Proctor and Gamble, a new version of Tide detergent was jointly developed by its Japanese unit and the company's HQ in Cincinnati. The first color television developed within Philips was not developed by its HQ, but by its Canadian foreign subsidiary unit. Clearly stated, innovation is not the mandated prerogative of the MNC's HQ. It is better that it is coordinately decentralized and well integrated with flexibilities.

In his insightful book, Managing Knowledge Workers: Unleashing Innovation and Productivity, Professor A.D. Amar (2002) cites that, compared to their old countries, the entering immigrants were much more innovative after they came to the USA because they felt that there less tied to rigid structures, they felt were fewer traditions, rules and restrictions, and that they could use their own initiative in dealing with newer challenges in their life in the new world. Using other arguments, he suggests that MNC's HQs should provide more flexible and general or broad (non-coercive) guidance, which should emphasize empathy, understanding, supportiveness and pro-active problem solving for the field managers at the lower level. A similar argument is provided by Mariann Jelinek in her 1979 landmark and enduring book, Institutionalizing Innovation, in which she cites studies of innovation in DuPont and General Motors. She decries the Fredrick Taylor-ian and other conventional approaches that recommend separating planning and coordination from the performance of a task. She argues that while such an approach frees up the management to pursue larger tasks of upper levels of management, complex organizations generally require an integrated and comprehensive grasp of the overall managerial role and organizational perspective. For example, the top line managers should be made active participants of the committees regarding these activities. The many arguments that Jelinek provides from the organizational theory literature are consistent with the Birkenshaw (2001) and Egelhoff (1984) tenets on similar issues of control in international organizations as they relate to improved, innovative performance. Similar tenets are put forward in the landmark, award winning, research-based, empirical book, New Patterns of Management, by Rensis Likert (1961).

In studying about how MNC HQ may deal with foreign subsidiary units, several authors (Aguzzoli and Geary, 2016; Birkenshaw, 1999, Birkenshaw, 2001; Gates, 1996; Roth \& Morrison, 1992, Williams, 2009) propose these MNC HQ-foreign subsidiary relationship styles: (a) HQ domination model; (b) rapid growth model: (i) HQ transfer resources and technologies to foreign subsidiary units, (ii) foreign subsidiary units obtain resources from host or third countries (this is the self-sufficiency model), and (c) combination of the two above methods; and (d) jointly planned and coordinated by $\mathrm{HQ}$ and foreign units in a good participative, partnership and collaborative spirit.

Growth of a global organization is an approach to be adopted with a broader perspective in that it should embrace the larger global and economic as well as cultural and political factors. A wider grasp of issues and mapping a larger picture would indeed further strengthen as we study the quality of HQ-subsidiary relationship activities by Asakawa (2001. The study supports the tenet that the "connected freedom" approach optimizes the foreign subsidiary units' performance. It is argued that an MNC's HQ must actively interact in such a way that both, the HQ and the foreign subsidiary units, feel that there is "high informational connectivity." And, yet there should be a "high degree of local autonomy." Thus, "high connected freedom" on the part of foreign subsidiaries is expected to lead to improved subsidiary performance, particularly with regards to creativity and innovation, as studied by Asakawa (2001). This is also the assumption utilized in this paper's tables.

\section{References}

Aguzzoli, R., \& Geary, J. (2016). Miners, politics and institutional caryatids: Accounting for the transfer of HRM practices in the Brazilian multinational enterprise. (2016). Journal of International Business Studies. RePEc:pal:jintbs:v:47:y:2016:i:8:d:10.1057. jibs.2016.24.

Amar, A. D. (2002). Managing knowledge workers: Unleashing innovation and productivity. Westport, CT: Quorom. 
Asakawa, K. (2001). Evolving headquarters-subsidiary dynamics in international R\&D: The case of Japanese multinationals. R\&D Management, 31(1), 1-14. https://doi.org/10.1111/1467-9310.00192

Barnum, C. (1994). US training manager becomes expatriate. HRM Magazine, 39(4), 82-96.

Begley, S. (2000). The nature of nurturing. Newsweek, March 27, 64-66.

Birkenshaw, J. (1999). The determinants and consequences of subsidiary initiative in multinational corporations. Entrepreneurship Theory and Practice, Fall, 24, 9-52. https://doi.org/10.1177/104225879902400102

Birkenshaw, J. (2001). Unleash innovation in foreign subsidiaries. Harvard Business Review, March, 79, 131-140.

Brief, A. P., Guzzo, R. A, \& Schneider, B. (1996). Creating a climate and culture for sustainable organizational change. Organizational Dynamics, Spring, 7-19.

Chang, E., \& Taylor, S. (1999). Control in multinational corporations (MNCs): The case of Korean manufacturing subsidiaries. Journal of Management, 24(4), 541-559. https://doi.org/10.1177/014920639902500404

Chawonec, G. D., \& Newstrom, C. N. (1981). International human resources management. Business Quarterly, 27(3), 82-96.

Collis, D., \& Montgomery, C. (1998). Creating corporate advantage. Harvard Business Review, 76(3), 70-83. https://doi.org/10.1057/palgrave.jibs.8490866

Compaq Computer Corporation. (2000). Annual Report, Houston, TX.

Duncan, W. J., Ginter, P. M., \& Swayne, L. E. (1998). Competitive advantage and internal organizational assessment. The Academy of Management Executive, 12(3), 6-16. https://doi.org/10.5465/ame.1998.1109046

Ebrahimi, B. P., \& Grieu, J. (1999). A multiple criteria of strategic decision aid for managers. International Journal of Management, 16(2), 287-293.

Egelhoff, W. G. (1984). Patterns of control in US, UK and European multinational corporations. Journal of International Business Studies, Fall, 73-83.

Evans, P., \& Lorange, P. (1989). The two logics behind human resource management. In P. Evans, Y. Doz and A. Laurent (eds.), Human Resource Management in In-International Firms, London: Macmillan, 144-161.

Finkelstein, S., \& Hambrick, D. (1996). Strategic leadership: Top executives and their effects on organizations. Minneapolis, MN: West Publishing.

Fish, A., \& J. Wood. (1996). A review of expatriate staffing practices in Australian business enterprises. International Journal of Human Resource Management, 7(4), 846-863. https://doi.org/10.1080/09585199600000159

Fortune. (2018). http://fortune.com/worlds-most-admired-companies/list/

Galphin, T. (1996). Connecting culture to organizational change. HR Magazine, 41, March, 84-86.

Gates, S., \& Engelhoff, W. (1986). Centralization in headquarters-subsidiary relationships. Journal of International Business Studies, Summer, 17, 71-93. https://doi.org/10.1057/palgrave.jibs.8490425

GE Annual Report 2017, Fairfield, CT.

Godiwalla, Y. H. (1997). Host country cultures and foreign subsidiary's management style and organizational culture. Proceedings of the Association for Global Business.

Godiwalla, Y. H. (2004). The making of the US foreign subsidiary CEO. 2004. Journal of Current Research in Global Business, Spring, 17(27), 52-66.

Godiwalla, Y. H. (2017). Training US managers for distant shores. International Journal of Business Administration, September, 8(6), 11-21. ISSN 1923-4007. E-ISSN 1923-4015. https://doi.org/10.5430/ijba.v8n6p11

Godiwalla, Y. H., \& Damanpour, F. (2004). Improving entrepreneurship and innovative strategy for foreign subsidiary units. Journal of Global Business, 15(29), Fall, 17-25.

Gupta, A. K., \& Govindarajan, V. (1991). Knowledge flows and the structure and control within multinational corporations. Academy of Management Review, 16, 768-792. https://doi.org/10.5465/amr.1991.4279628

Haddock, C., \& South, B. (1996). How Shell's Organization and HR practices help it to be both global and local. In International Human Resource Management, London: Prentice-Hall.

Hamel, G. (1998). Strategy innovation. Executive Excellence, August, 15(8), 7-8.

Harris, C. (1997). Capitalizing on the global workforce: A strategic guide for expatriate management. The China Business Review, September-October, 91-104.

Hart, A. B., Ferleger, A., \& Herbert, R. (1989). Theodore Roosevelt Cyclopedia (CD-ROM). Theodore Roosevelt Association., 534-535.

Harvard Management Update. (2000). The new uses of intranets. 5(5), May, 4-5. 
Ioannou, L. (1994). Cultivating the new expatriate executive. International Business, July, 43-60.

Jelinek, M. (1979). Institutionalizing Innovation, New York: Praeger Publishers.

Kamoche, K. (1996). The integration-differentiation puzzle: A resource-capability perspective in international human resource management. The International Journal of Human Resource Management, 7(1), 230-244. https://doi.org/10.1080/09585199600000126

Laabs, J. J. (1996). Global HR inroads paved at conference: HR pioneers explore the road less traveled, in Global Business Leadership Through HR Conference. Personnel Journal, 75(2), 70-94.

Likert, R. (1961). New Patterns of Management. New York, NY: McGraw-Hill.

McLaughlin, D., \& Smith, G. (1999). Gaining a competitive: Building business from knowledge. Strategy and Leadership, March/April, 27(2), 36-37.

McNerney, D. J. (1996). Global staffing: Some common problems and solutions. HR Focus, 73(6), 1-6.

Morris, B. (2000). So you're a player. Do You Need a Coach? Fortune, (February 21, 2000), 144-154.

Muralidharan, R., \&. Phatak, A. (1979). International R\&D Activity of US MNCs: An Empirical Study with Implications for Host Government Policy. Multinational Business Review, Fall, 7(2), 97-108.

Newsweek. Touring Muslim Style. (2000). July 10, 79.

Nohria, N., \& Ghoshal, S. (1994). Differentiated fit and shared values: Alternatives for managing headquarters-subsidiary relations. Strategic Management Journal, 15, 491-502. https://doi.org/10.1002/smj.4250150606

Otterbeck, L. (Ed.). (1981). The Management of Headquarters-Subsidiary Relationships in Multi-national Corporations. NY, New York: St. Martin Press.

Pauly, L. W., \& and Reich, S. (1997), National structures and multinational corporate behavior: enduring differences in the age of globalization. International Organization, 51(1), 1-30. https://doi.org/10.1162/002081897550285

Porter, M. (1997). Creating advantages. Executive Excellence, December, 14(12), 17-18.

Robertson, C., \& Fadil, A. (1999). Ethical decision-making in multinational organizations: A culture based model. Journal of Business Ethics, 19, 385. https://doi.org/10.1023/A:1005742016867

Rosenzweig, P. M., \& Singh, J. V. (1991). Organizational environments and the multinational environments. Academy of Management Review, 16, 340-361. https://doi.org/10.5465/amr.1991.4278953

Roth, K., \& Morrison, A. (1992). Implementing global strategy: characteristics of global subsidiary mandates. Journal of International Business Studies, 23, 715-750. https://doi.org/10.1057/palgrave.jibs.8490285

Salmons, J. (2015). Language shift and the Indo-Europanization of Europe. In (edited) Mailhammer, R., Vennemann, T., \& Olsen, B. A.. Origin and Development of European Languages. Copenhagen, Denmark: Museum Tusculanum Press.

Schellenbarger, S. (2000). Now day-care centers have started helping stressed parents too. The Wall Street Journal, April 19, B-1.

Sundaraman, A. K., \& Black, J. S. (1992). The environment and the internal organization of multinational enterprises. Academy of Management Review, 17, 729-757. https://doi.org/10.5465/amr.1992.4279065

Tsien, J. Z. (2000). Building a Brainier Mouse. Scientific American, 282, 62-68. https://doi.org/10.1038/scientificamerican0400-62

Vachani, S. (1995). Enhancing the obsolescing bargain theory: A longitudinal study of foreign ownership of U.S. and European multinationals. Journal of International Business Studies, 26(1), 159-173. https://doi.org/10.1057/palgrave.jibs.8490170

Want, J. (1993). Managing radical change. Journal of Business Strategy, 15, 21-28. https://doi.org/10.1108/eb039555

Williams, C. (2009). Subsidiary-level determinants of global initiatives in multinational corporations. Journal of International Management, 15(1), 92-104. https://doi.org/10.1016/j.intman.2008.03.002

\section{Copyrights}

Copyright for this article is retained by the author(s), with first publication rights granted to the journal.

This is an open-access article distributed under the terms and conditions of the Creative Commons Attribution license which permits unrestricted use, distribution, and reproduction in any medium, provided the original work is properly cited. 